Acta vet. scand. $1978,19,58-72$.

From the State Veterinary Serum Laboratory, Copenhagen, and the Tuberculosis Department, Statens Seruminstitut, Copenhagen, Denmark.

\title{
EXPERIMENTAL INFECTION WITH MYCOBACTERIUM AVIUM, SEROTYPE 2, IN PIGS
}

\section{CONTACT INFECTION FROM ORALLY INOCULATED PIGS *}

\author{
By \\ J. Berg Jørgensen
}

JØRGENSEN, J. BERG: Experimental infection with Mycobacterium avium, Serotype 2, in pigs. 4. Contact infection from orally inoculated pigs. Acta vet. scand. 1978, 19, 58-72. - In 3 experiments, 13 pigs were inoculated orally with $0.5 \mathrm{mg}$ Mycobacterium avium daily for 5 days $\left(1 \mathrm{mg}=32-68 \times 10^{6}\right.$ viable units $)$. Five to 8 days after inoculation, 16 non-inoculated pigs were added to the inoculated pigs.

Cultures from faeces showed excretion of M. avium from all the inoculated pigs for some time within the period 16 to 65 days after the last inoculation; the greatest numbers of organisms $(62000$ per $100 \mathrm{~g}$ faeces) were found at about the middle of the excretion period (Table $2)$. Two of the contact pigs were found to excrete $M$. avium in small numbers, 1 at 15, the other at 37 and 44 days after contact.

All the inoculated pigs and 13 of the contact pigs showed positive intradermal tuberculin reactions. Post-mortem examination showed tuberculous lesions in all the inoculated pigs (Table 3). M. avium was transmitted to 15 of 16 pigs by contact. Five of these pigs showed gross lesions, 10 of them microscopic lesions only; in 9 of them the infection was proved by culture.

Mycobacterium avium, Serotype 2; oral inoculation; excretion; contact infection; pigs.

The significance of transmission of Mycobacterium (M.) avium infection among pigs is still doubtful. Reports have been published about contact infection (Graham \& Tunnicliff 1926, Gwatkin \& Mitchell 1952 and others) and descriptions been given

* This report is the result of a project planned and carried out in cooperation with dr. H. Chr. Engbæk and dr. A. Jespersen, both of the Tuberculosis Department, Statens Seruminstitut, Copenhagen, Denmark. 
of cases of tuberculous enteritis which may without doubt have involved an excretion of organisms with the faeces (Griffith 1911, Folger 1938, Lautrup-Nielsen 1975).

The present paper is a report of 3 experiments aiming at a quantitative study of the excretion of $M$. avium with the faeces of orally inoculated pigs, and at determining the duration of such excretion. Further, the significance of transmission of $M$. avium to non-infected pen mates was examined.

\section{MATERIAL AND METHODS}

Experimental animals. Table 1 gives a survey of the experimental pigs, which were either littermates or borne by different sows within a period of 5 days. The ages given in Table 1 are mean ages. If all pigs in a group have been necropsied within a period of 7 days, figures for age and weight and number of days in experiment are given as means for the whole group. In Experiment (Exp.) 13, 4 pigs were inoculated and 5 kept as non-infected controls; in Exp. 15: 5 inoculated and 6 controls; and in Exp. 16: 4 inoculated and 5 controls.

Inoculation material. Strain SSC 1336 (ATCC 25291) of chicken origin (Engbæk et al. 1971) was used in all 3 experiments. For culture preparation, viable unit counts and checking of colony morphology, see Jørgensen (1977 a). Viable unit counts per mg after 8 weeks were as follows: Exp. No. 13, $68 \times 10^{6}$; No. $15,32 \times 10^{6}$; and No. $16,51 \times 10^{6}$. Colonies were mainly smooth transparent ( $\mathrm{SmT}$ ) with a few $\mathrm{D}$ and $\mathrm{R}$ variants (Fregnan \& Smith 1962). The virulence of the strain was checked on rabbits by intravenous inoculation of $1 \mathrm{mg}$ organisms, 1 rabbit per experiment. The animals died after 16, 19 and 15 days, respectively.

Inoculation. The culture, suspended in skimmilk, was administered individually by mouth, $0.5 \mathrm{mg}$ organisms per pig daily for 5 days in all 3 experiments. The infected pigs were kept isolated for a further 5 to 8 days and then put together with the non-infected pigs in a clean room. During the period of contact it was endeavoured to keep the standard of hygiene, especially as regards removal of faeces, at the same level as in most Danish herds of swine.

Tuberculin tests with avian and human PPD tuberculins, 1000 t.u. per dose, were performed and evaluated as described previously (J $\phi r g e n s e n 1977$ a). All pigs were tested before the experi- 
ments. In Exps. 13 and 16 the pigs were tested 28 and 27 days after the first inoculation, respectively, and subsequently at 28day intervals. In Exp. 15 tests were made 42 and 58 days after inoculation. The non-infected pen mates were tested on the same occasions as the infected pigs, beginning at 19,31 and 14 days after contact had been established (Exps. 13, 15 and 16). In Exp. 16 an extra test was performed on the 3 contact pigs alive on Day 170.

Cultures were made from faeces samples collected from the rectum. One sample from each pig was examined before the start of the experiments. In Exp. 13 samples were taken on Day 6 of the isolation period and 21 days after the last inoculation, and thereafter at 14-day intervals. In Exps. 15 and 16 samples were taken daily during the inoculation and isolation period, then on Day 9 after the last inoculation, and thereafter at 7-day intervals. The controls were tested on the same occasions as the infected pigs.

Technique. About $2 \mathrm{~g}$ faeces was decontaminated with $10 \mathrm{ml}$ $4 \%$ sodium hydroxide for $10 \mathrm{~min}$. and with $10 \mathrm{ml} 5 \%$ oxalic acid with $0.1 \%$ malachite green for $15 \mathrm{~min}$. (Beerwerth 1967). The sediment was then suspended in $4 \mathrm{ml}$ diluted Sauton medium and $0.1 \mathrm{ml}$ of the suspension inoculated onto 4 slants of Löwen. stein-Jensen (L-J) medium and 4 slants of L-J medium with 0.5 mg Actidione ${ }^{\star}$ per ml. Viable units were counted after incubation for 8 weeks at $37^{\circ} \mathrm{C}$. To check the identity of the recovered organisms, subcultures were grown on L-J medium at $22^{\circ}, 37^{\circ}$ and $45^{\circ} \mathrm{C}$. The criteria of $\mathrm{M}$. avium were: nonchromogenic, smooth, dome-shaped colonies, growth at $22^{\circ} \mathrm{C}$ and $45^{\circ} \mathrm{C}$ in about 6 weeks and at $37^{\circ} \mathrm{C}$ in about 2 weeks. $A$ few of the isolated strains were inoculated on rabbits, $1 \mathrm{mg}$ i.v., and/or tested biochemically by amidase tests (Bönicke 1960) using amides Nos. 3 (urea), 5 (nicotinamide) and 6 (pyrazinamide), and by Tween 80 degradation test, catalase test and nitrate test (Wayne 1962 a, b).

Duration of the experiments is indicated in Table 1.

Post-mortem examinations included macroscopic and histopathological examination (Jørgensen 1977 a) and culture (J $\phi r-$

* Cycloheximide, Koch-Light Laboratories Ltd., Coinbrook, Bucks., England. 
T a b l e 1. Survey of experimental animals, duration of experiments, and weights at slaughter.

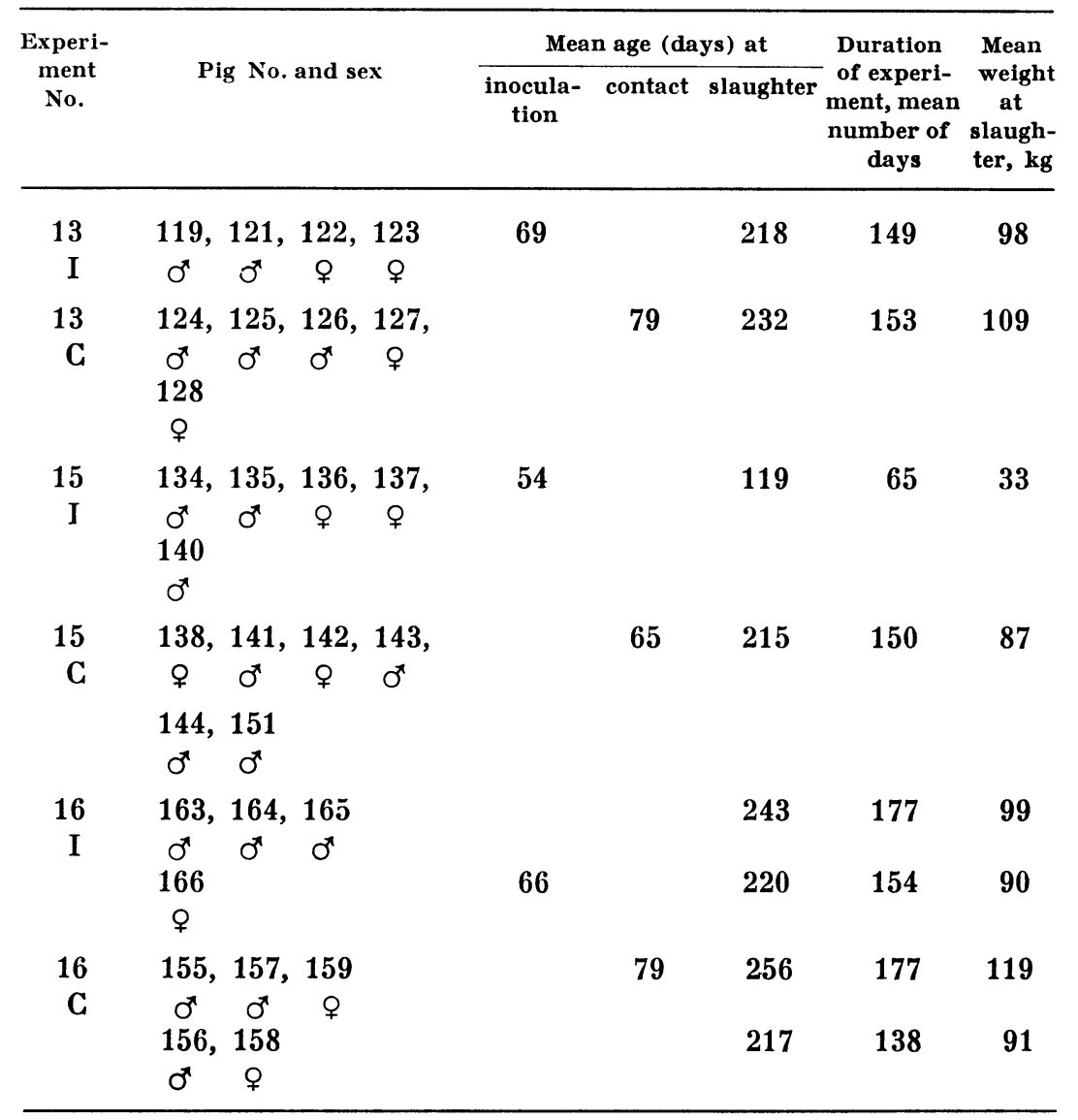

I = Inoculated by mouth.

$\mathrm{C}=$ Non-inoculated controls.

gensen $1977 \mathrm{~b}$ ). The intestinal contents were decontaminated by the method of Beerwerth. The materials examined are listed in Tables 4 and 5 .

\section{RESULTS}

Tuberculin tests. None of the pigs showed reaction before inoculation. All the inoculated pigs showed delayed hypersensitivity, 1 pig 28 days after the first inoculation, the rest of the pigs after $55-58$ days. The mean 24-hr. reactions of the 8 inoculated pigs in Exps. 13 and 16 are shown in Fig. 1. The strongest 


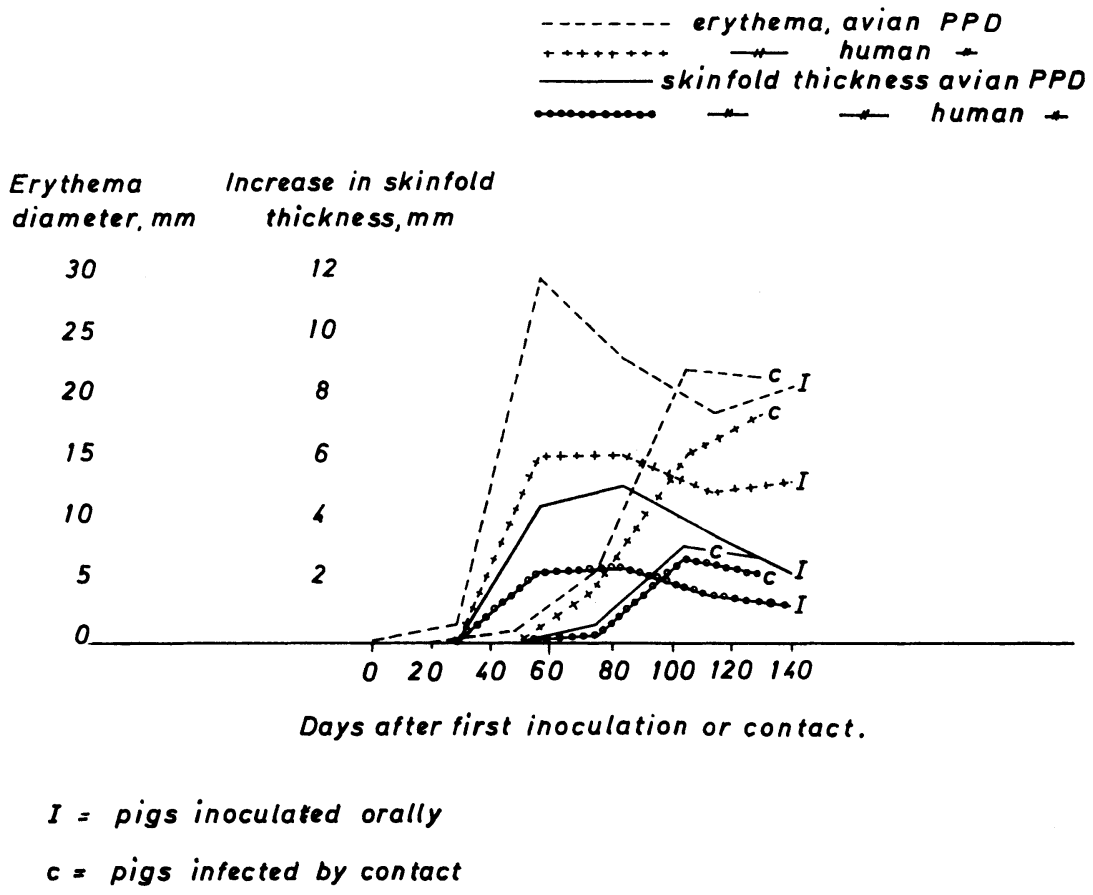

Figure 1. Mean reactions to PPD avian and human, 1000 t.u. per dose, in 8 pigs inoculated orally with $0.5 \mathrm{mg}$ M. avium daily for 5 days, and in 5 pigs showing gross lesions after contact infection. Readings after 24 hrs.

reactions were found 55 (56) and 83 (84) days after inoculation. On Days 139 and 140 the reactivity was still present, but weaker. Among the contact pigs the most pronounced reactions were seen in the 5 pigs in Exp. 13 which showed gross lesions. The mean reactions of these pigs are shown in Fig. 1. On Days 103 and 131 their reactivity was at about the same level as that of the inoculated pigs. Eight of 11 contact pigs without gross lesions (Exps. 15 and 16) showed hypersensitivity. Table 2 shows the reactions of 7 of these pigs as read at 24 hrs. Pig 155, which reacted on Day 98 after contact, but at the 48-hr. reading only, is not included. The table shows that the onset of hypersensitivity (115-154 days) was slower in these pigs than in the contact pigs with gross lesions, and that the level of hypersensitivity was lower. Most reacting animals responded to both tuberculins, though as a whole with the strongest reaction to avian tuberculin. Further details about the tuberculin tests will be published in a subsequent paper (Jørgensen \& Weis Bentzon, in preparation). 
T a b l e 2. Comparative tuberculin tests with PPD avian and human, 1000 t. u. per dose, on contact pigs with no gross lesions. Reactions as read at 24 hrs. Negative animals not listed.

\begin{tabular}{|c|c|c|c|c|c|c|}
\hline \multirow{2}{*}{$\begin{array}{c}\text { Experi- } \\
\text { ment } \\
\text { No. }\end{array}$} & \multirow{2}{*}{$\begin{array}{l}\text { Pig } \\
\text { No. }\end{array}$} & \multirow{2}{*}{$\begin{array}{l}\text { Days after } \\
\text { first con- } \\
\text { tact }\end{array}$} & \multicolumn{2}{|c|}{$\begin{array}{l}\text { Increase in skinfold } \\
\text { thickness, mm }\end{array}$} & \multicolumn{2}{|c|}{$\begin{array}{c}\text { Erythema, diameter } \\
\text { mm }\end{array}$} \\
\hline & & & avian & human & avian & human \\
\hline 15 & 138 & 143 & 2.0 & 1.0 & 12.8 & 11.6 \\
\hline - - & 141 & 143 & 2.0 & 1.5 & 14.4 & 11.6 \\
\hline- & 143 & 115 & 1.0 & 0 & 9.0 & 0 \\
\hline-- & 151 & 115 & 1.0 & 1.0 & 11.0 & 9.0 \\
\hline- & 151 & 143 & 3.0 & 1.5 & 17.4 & 12.6 \\
\hline 16 & 156 & 126 & 0 & 0 & 10.5 & 0 \\
\hline- & 158 & 126 & 1.0 & 1.0 & 12.5 & 11.0 \\
\hline- & 159 & 154 & 1.0 & 0 & 8.5 & 9.0 \\
\hline - & 159 & 170 & 0 & 0 & 10.5 & 0 \\
\hline
\end{tabular}

Explanations: In Exp. 15 tests were made on days 31, 59, 87, 115 and 143 after contact. Pigs 142 and 144 were negative at all tests. In Exp. 16 tests were made on days 14, 42, 70,98 and 126 after contact (all pigs) and on days 154 and 170 (Pigs 155, 157 and 159). Pigs 155 and 157 were negative at all $24-\mathrm{hr}$. readings.

Cultures from faeces. All samples collected before the start of the experiments were negative. In Exp. 13 the samples collected on Day 6 after the last ionculation were negative. In Exp. 15 there was excretion from Day 2 of the inoculation period to Day 1 or 2 after the last inoculation, with viable unit counts from 500 to 62000 per 100 g faeces. In Exp. 16 irregular excretion was found during the infection period, but not during the rest of the isolation period. Table 3 shows the results of cultures from the inoculated pigs during their contact with non-inoculated pigs. In Exp. 13 excretion was found on Days 21 and 35, and in Exp. 15 on Day 16 to Day 58, with the heaviest excretion from Day 30 to Day 51. In Exp. 16, the first positive samples were found on Day 30 and the last on Day 65. The heaviest excretion was found on Days 37 and 44. Two of the contact pigs were positive. Thus, in Exp. 13, Pig 125 was positive on Day 15 after the first contact, with about 1000 viable units per $100 \mathrm{~g}$ faeces, and in Exp. 15 Pig 151 was positive on Days 36 and 43 with viable unit counts of about 500 on both days. In Exps. 15 and 16 growth appeared of slightly yellow, rough colonies, which differed from colonies of 
T a ble 3. Pigs infected orally with $\mathrm{M}$. avium, $0.5 \mathrm{mg}$ daily for 5 days. Excretion of M. avium in faeces, viable units per $100 \mathrm{~g}$ faeces.

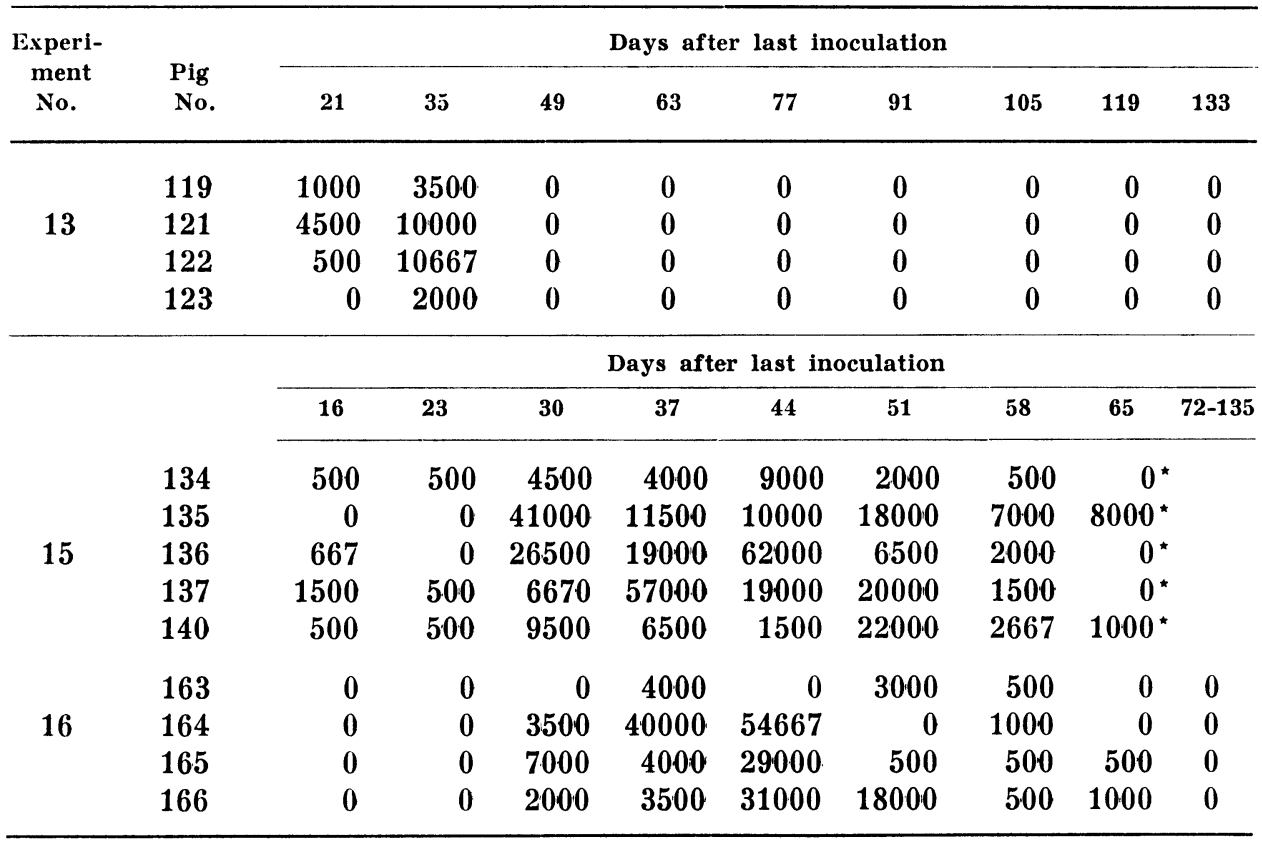

* Culture from rectal contents at necropsy 61 days after the last inoculation.

M. avium by faster growth at $22^{\circ} \mathrm{C}\left(7-14\right.$ days) and $37^{\circ} \mathrm{C}$ ( 7 days) and by not growing at all at $45^{\circ} \mathrm{C}$. Being non-virulent for rabbits, positive in the nitrate, catalase and Tween- 80 degradation tests, and negative in the amidase tests (amides 3,5 and 6) they were identified as M. triviale.

Necropsy. Table 4 shows the distribution of macro- and microscopic lesions. All the inoculated pigs showed gross lesions. Pigs necropsied 65 days after the first inoculation (Exp. 15) showed caseated lesions, $0.5-3 \mathrm{~mm}$ in diameter, with signs of acute inflammation. Two of these pigs $(137,140)$ showed tuberculous ulcers in the Peyer patches. In pigs necropsied 149-177 days after inoculation the lesions were well-defined, caseo-calcareous. Lesions of the same type were found in the contact pigs in Exp. 13. In Exps. 15 and 16 the contact pigs showed no gross lesions.

Histopathology. Animals examined 65 days after the first inoculation showed epithelioid tubercles with or without casea- 
tion and slight calcification, and with a distinct tendency to demarcation and organization by fibrous tissue.

In the Peyer patches microgranulomas were seen in all 5 pigs and ulcers in 2. At 149-177 days after inoculation the lesions were caseo-calcareous and lined with epithelioid cells, lymphocytes and eosinophiles, and surrounded by a capsule of fibrous tissue. Besides such chronic lesions microgranulomas were seen with or without fibrous tissue demarcation. Similar lesions were seen in the contact pigs in Exp. 13 (with gross lesions). Of the contact pigs in Exps. 15 and 16 (with no gross lesions) all except Pig 144 showed microgranulomas in the tissues listed in Table 4. These granulomas consisted almost entirely of giant cells.

Culture. The results are given in Table 5 .

Inoculated pigs. Five pigs (Exp. 15) examined 65 days after the first inoculation were positive, mostly with high viable unit counts. Four pigs (Exp. 13) examined 149 days after inoculation, and Pig 166 (Exp. 16) examined after 154 days, were positive with low viable unit counts, while 3 pigs (Nos. 163, 164 and 165 , Exp. 16) examined after 177 days were negative.

Contact pigs. Nine of 16 pigs were positive, viz. the 5 pigs in Exp. 13, 3 of 6 pigs in Exp. 15, and 1 of 5 pigs in Exp. 16 (Table 5).

\section{DISCUSSION}

Previous experiments have proved that on oral inoculation in doses ranging from 100 to $200 \times 10^{6}$ organisms divided over 5 to 15 days, M. avium is capable of producing manifest tuberculous infection (Jørgensen $1977 \mathrm{~b}, 1978$ ). The results of the oral inoculations in the present experiments have confirmed this finding and offered an opportunity to study the pathogenesis of the infection in its later stages.

In the tissues of pigs killed 65 days after the first inoculation, histological and bacteriological examinations showed about the same distribution of lesions and the same number and distribution of acid-fast organisms as found previously in 2 pigs inoculated with, respectively, $92.5 \times 10^{6}$ and $234 \times 10^{6}$ organisms, and killed 35 and 50 days after the first inoculation, respectively. In pigs killed on Day 35 the lesions were of granulomatous nature; caseation was found on Day 50, and on Day 65 calcification was apparent. Connective-tissue demarcation was found in pigs killed on Days 50 and 65. 
T a b l e 4. Results of pathological examination.

\begin{tabular}{|c|c|c|c|c|c|c|c|c|c|c|c|c|}
\hline \multirow[b]{2}{*}{ Pig No. } & \multicolumn{9}{|c|}{ Experiment 13} & \multirow[b]{2}{*}{134} & \multirow[b]{2}{*}{135} & \multirow[b]{2}{*}{136} \\
\hline & 119 & 121 & 122 & 123 & 124 & 125 & 126 & 127 & 128 & & & \\
\hline Mode of infection & I & I & I & I & C & C & C & C & C & I & I & I \\
\hline Days in experiment & 149 & 149 & 149 & 149 & 153 & 153 & 153 & 153 & 153 & 65 & 65 & 65 \\
\hline
\end{tabular}

No. Tissue

1 Ln. mandibularis

$$
(+)(+) \quad(+) \quad(+) \quad(+) \quad(+) \quad(+) \quad(+)(+) \quad(+)
$$

2 Ln. parotideus

4 Ln. retrophar. med.

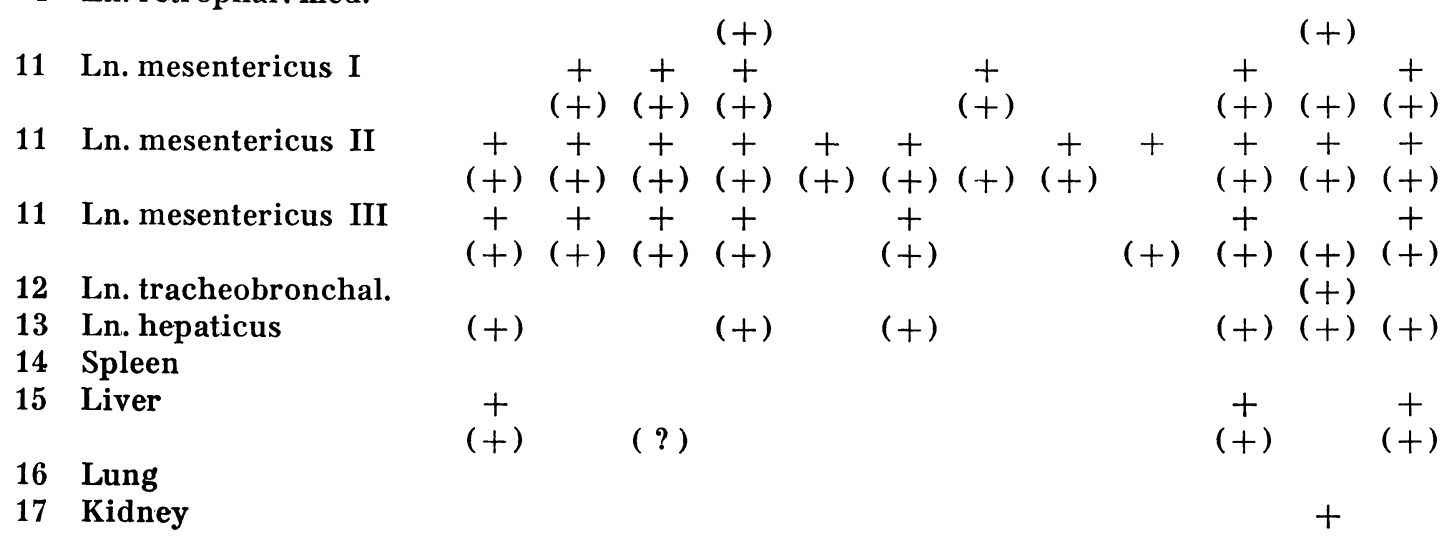

19 Musc. long. dorsi

25 Tonsil

27 Intestinal mucosa (Peyer patch)

$$
\begin{aligned}
& (+)(+) \\
& (+)
\end{aligned}
$$$$
(+)(+)
$$$$
(+)
$$$$
(+)(+)(+)(+)
$$

Explanations:

$\mathrm{I}=$ Inoculated by mouth. $\quad \mathrm{C}=$ Non-inoculated, in-contact.

Figures without brackets indicate gross lesions.

Figures in brackets indicate microscopic lesions.

In the present experiments a reduction in the number of tissues with macro- or microscopic lesions occurred between Day 65 and Days 149-177. Cultures showed a drastic reduction of viable acid-fast organisms from Day 65 to Day 149 (154) and at 177 days after inoculation no viable acid-fasts were found, i.e. the pigs had apparently overcome the infection.

Griffith (1911) and Graham \& Tunnicliff (1926) reported on excretion of $M$. avium in the faeces of infected pigs, as proved by, respectively, microscopy and inoculation on chickens. Trans- 


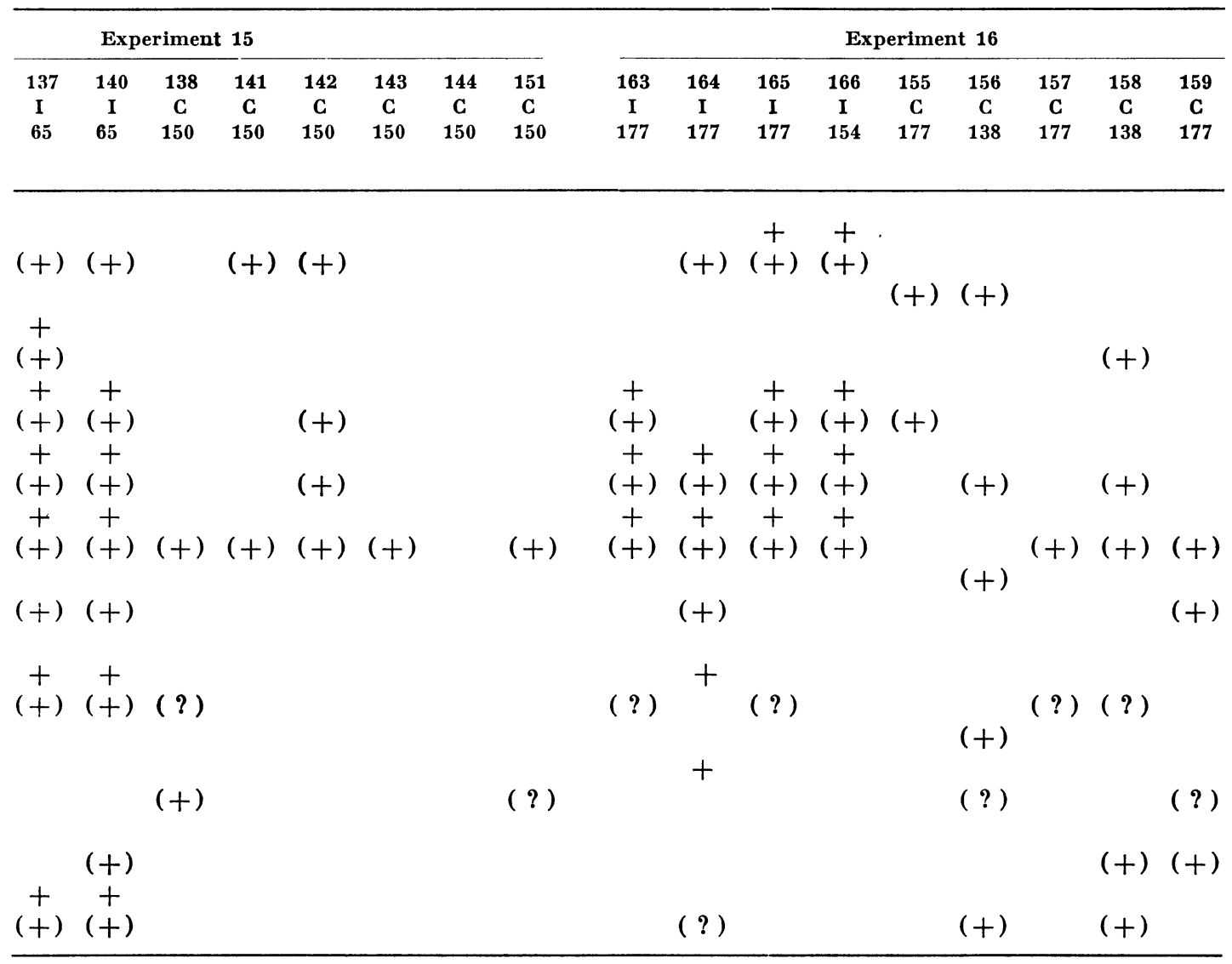

Blank space $=$ No abnormalities.

(?) =- Lymphocyte accumulations.

mission of M. avium or M. intracellulare among pigs after experimental infection has been described by Graham \& Tunnicliff, Gwatkin \& Mitchell (1952), Kauker \& Zettl (1964), Ray (1966), Tuffley et al. (1973) and Thoen et al. (1976).

So far, no data are available on the duration of the excretion or the quantity of organisms excreted. In the present work all the artificially infected pigs excreted M. avium for periods of varying length between Day 16 and Day 65 after the last of 5 inoculations. The heaviest excretion was found at about the middle of the excretion period with maximum 62000 organisms per $100 \mathrm{~g}$ faeces. In Exp. 13, the excretion would seem to have been heavier than 
T a b l e 5. Results of culturing.

\begin{tabular}{|c|c|c|c|c|c|c|c|c|c|c|}
\hline \multirow{2}{*}{\multicolumn{2}{|c|}{$\begin{array}{r}\text { Pig No. } \\
\text { Mode of infection } \\
\text { Days in experiment }\end{array}$}} & \multicolumn{9}{|c|}{ Experiment 13} \\
\hline & & $\begin{array}{c}119 \\
I \\
149\end{array}$ & $\begin{array}{c}121 \\
\text { I } \\
149\end{array}$ & $\begin{array}{c}122 \\
\text { I } \\
149\end{array}$ & $\begin{array}{c}123 \\
\text { I } \\
149\end{array}$ & $\begin{array}{c}124 \\
\text { C } \\
153\end{array}$ & $\begin{array}{c}125 \\
\text { C } \\
153\end{array}$ & $\begin{array}{c}126 \\
\text { C } \\
153\end{array}$ & $\begin{array}{c}127 \\
\text { C } \\
153\end{array}$ & $\begin{array}{c}128 \\
\mathrm{C} \\
153\end{array}$ \\
\hline No. & Tissue & & & & & & & & & \\
\hline 1 & Ln. mandibularis & 40 & & 160 & & $\infty$ & 3560 & 610 & 10 & 400 \\
\hline 2 & Ln. parotideus & & & & & & & & & \\
\hline 4 & Ln. retrophar. med. & 10 & 490 & & 130 & & & & & \\
\hline 11 & Ln. mesentericus I & 40 & 200 & & 20 & & & 19700 & & \\
\hline 11 & Ln. mesentericus II & & 10 & 300 & 20 & & 1000 & & & \\
\hline 11 & Ln. mesentericus III & 30 & 470 & 480 & 260 & & & & & \\
\hline 12 & Ln. tracheobronchal. sin. & & & & & & & & 10 & \\
\hline 13 & Ln. hepaticus & 10 & 20 & 140 & 90 & 170 & 10 & 10 & 20 & 30 \\
\hline 14 & Spleen & & & & & & & & & \\
\hline 15 & Liver & & & & & & & & & \\
\hline 16 & Lung & & & & & & & & & \\
\hline 17 & Kidney & & & & & & & & & \\
\hline 19 & Musc. long. dorsi & & & & & & & & & \\
\hline 25 & Tonsil & 60 & 1100 & 110 & 1450 & & & 1000 & & \\
\hline 27 & $\begin{array}{l}\text { Intestinal mucosa } \\
\text { (Peyer patch) }\end{array}$ & & & & & & & & & \\
\hline 281 & Intestinal contents & & & & & & & & & \\
\hline 28II & & & & & & & & & & \\
\hline
\end{tabular}

Explanations:

$\mathrm{I}=$ Inoculated by mouth. $\quad \mathrm{C}=$ Non-inoculated, in-contact.

Blank space $=$ No growth.

indicated by the results of cultures from faeces (Table 3 ) in that all of the 5 contact pigs in this experiment showed gross lesions (Table 4). The short excretion period observed in this experiment is difficult to explain, but may be due to shortcomings of the cultural procedure.

M. avium was transmitted by contact to 15 of 16 pigs, as indicated by the results of pathological and cultural examination and tuberculin tests. Most convincing, of course, was the isolation of M. avium from 9 pigs. In 5 of these, gross lesions were found. A cellular reaction (epithelioid cells and giant cells) indicative of tuberculous infection was found in $\mathbf{1 0}$ pigs without gross lesions (Table 5). Thirteen of the contact pigs showed delayed hypersensitivity to tuberculin, most pronounced in the pigs with gross 


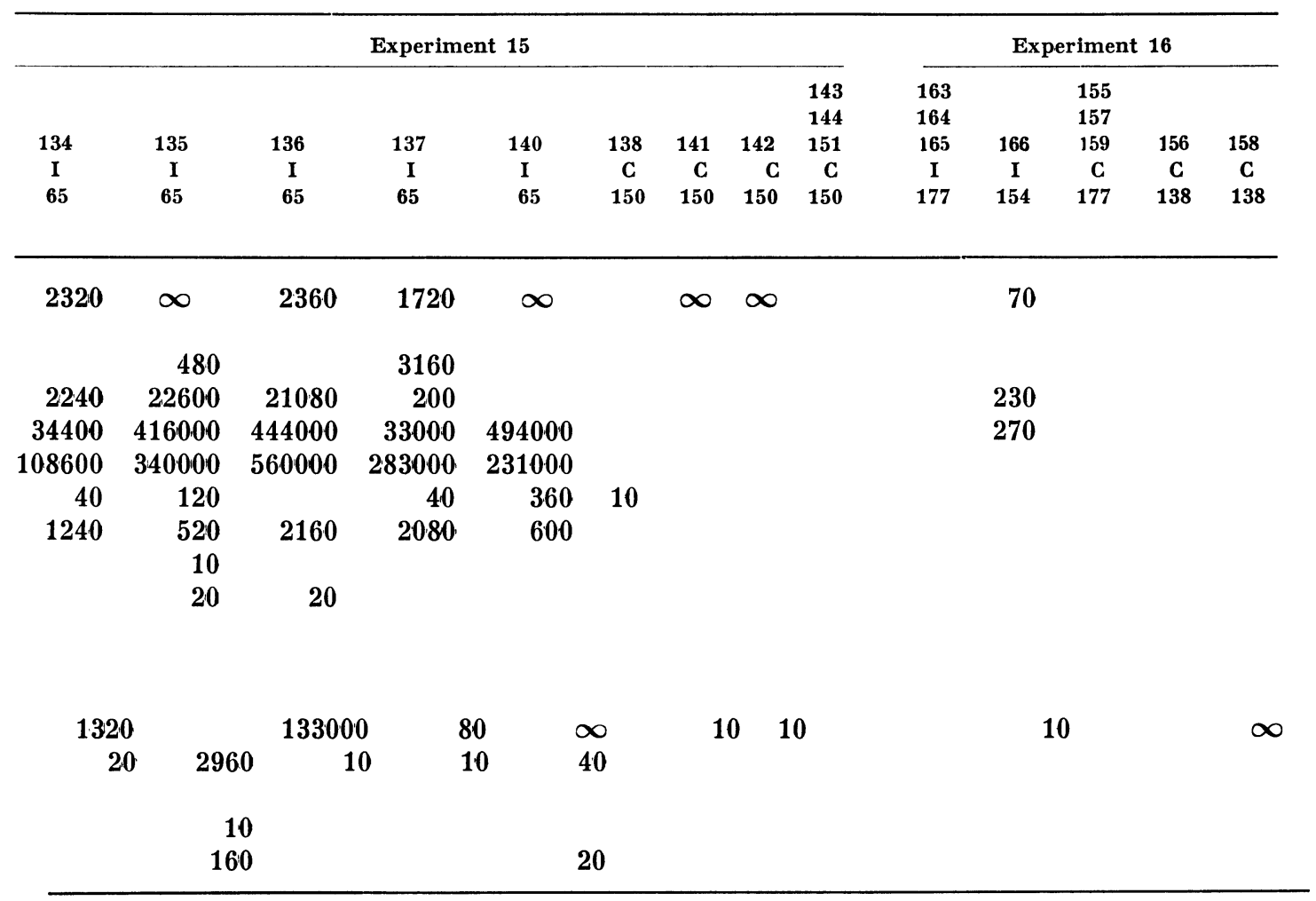

Figures indicate viable units per $0.5 \mathrm{~g}$ tissue or $2 \mathrm{~g}$ intestinal contents. $\infty=>400000$ units.

lesions, the reactions of which were comparable to those of the inoculated pigs, though with a delay of 1 to 2 months in the onset of hypersensitivity, as reckoned from the first day of exposure to infection. Of the 11 contact pigs without gross lesions 8 showed hypersensitivity, but with weaker reactions and an even greater delay in the onset of hypersensitivity than in the contact pigs with gross lesions.

The results indicate that among pigs exposed to contact infection sensitivity to tuberculin may be expected from about $\mathbf{7 5}$ to about $\mathbf{1 5 0}$ days after exposure, presumably depending on the dose of infection.

Only 1 pig was negative at all examinations.

Two of the contact pigs were found to excrete M. avium in the faeces, 1 at 15 days, the other at 37 and 44 days after the first 
contact. Since it is hardly credible that a tuberculous enteritis should have developed within $\mathbf{1 5}$ days, the finding in the firstmentioned pig was probably due to a simple passage of ingested organisms. In the last-mentioned pig a slight and transient tuberculous enteritis may have developed.

In a previous experiment Jørgensen (1978) found that the minimum oral dose of $M$. avium capable of producing manifest tuberculous infection in pigs was between $23.4 \times 10^{5}$ and $23.4 \times 10^{6}$ viable units. In the present experiments 5 of 16 contact pigs ingested enough organisms for gross lesions to develop, while 10 pigs developed microscopic lesions only. No doubt the environmental burden of infective organisms was so low that minor fluctuations in that burden might determine whether manifest infection would be induced in the exposed pigs or not. Graham \& Tunnicliff concluded that "the transmission from infected to healthy pigs through association appears to be slower than from infected chickens to pig following comparable contact".

Cultures from faeces showed that there was little or no excretion of M. avium from the contact pigs. Maintenance of the infection in a herd of swine would therefore seem to be impossible, unless infection is continuously introduced from the outside.

According to experiences from natural cases, M. avium infection among swine has a definite tendency to disappear within 4-12 months (Biering-Sфrensen 1959, J $\phi$ rgensen et al. 1972) and the present results confirm these findings.

\section{REFERENCES}

Beerwerth, W.: Die Züchtung von Mykobakterien aus dem Kot der Haustiere und ihre Bedeutung für die Epidemiologie der Tuberkulose. (Culture of mycobacteria from the faeces of domestic animals and their significance for the epidemiology of tuberculosis). Prax. Pneumol. 1967, 21, 189-202.

Biering-Sфrensen, $U$.: Ophobning af tilfælde af aviær tuberkulose i en svinebesætning. (Cases of avian tuberculosis infection in a herd of pigs). Medlemsbl. danske Dyrlægeforen. 1959, 42, 550-552.

Bönicke, R.: Die Klassifizierung ,atypischer“ Mykobakterien durch Bestimmung ihrer unterschiedlichen acylamidatischen Stoffwechselleistungen. (Classification of atypical mycobacteria on the basis of their different amidaseactivity). Tuberk.-Arzt. 1960, 14, $209-216$.

Engbæk, H. C., E. H. Runyon \& A. G. Karlson: Mycobacterium avium Chester. Designation of the neotype strain. Int. J. system. Bact. 1971, 21, 192-196. 
Fregnan, G. B. \& D. W. Smith: Description of various colony forms of mycobacteria. J. Bact. 1962, 83, 819-827.

F $\phi$ lger, $A$. F.: Uber einige bemerkenswerte tuberkulöse Primärkomplexe im Darmkanal vom Rind und Schwein. (Some remarkable tuberculous primary complexes in the intestines of cattle and pig). Acta path. microbiol. scand. 1938, Suppl. 37, 179-191.

Graham, R. \& E. A. Tunnicliff: Fowl tuberculosis in swine. Trans. Illinois State Acad. Sci. 1926, 19, 138-143.

Griffith, F.: Investigation of avian tubercle bacilli obtained from birds and swine. In Final report of the Royal Commission on Tuberculosis. Part 2, app. vol. 4, p. 167-382, Darling and Son, London 1911.

Gwatkin, R. \& C. A. Mitchell: Avian tuberculosis infection in swine. Canad. J. comp. Med. 1952, 16, 345-347.

Jørgensen, J. B.: Experimental infection with Mycobacterium avium, Serotype 2, in pigs. 1. Intravenous inoculations. Acta vet. scand. 1977 a, 18, $532-544$.

Jørgensen, J. B.: Experimental infection with Mycobacterium avium, Serotype 2, in pigs. 2. Oral infection with large doses of $M$. avium. Acta vet. scand. $1977 \mathrm{~b}, 18,545-558$.

Jørgensen, J. B.: Experimental infection with Mycobacterium avium, Serotype 2, in pigs. 3. Oral infection with small doses of $M$. avium. Acta vet. scand. 1978, 19, $49-57$.

Jørgensen, J. B., K. Haarbo, A. Dam \& H. C. Engbæk: An enzootic of pulmonary tuberculosis in pigs caused by M. avium. 1. Epidemiological and pathological studies. Acta vet. scand. 1972, 13, 56-67.

Kauker, E. \& K. Zettl: Beitrag zur käsigen Lymphknotenentzündung der Schweine. (Report on caseous inflammation of lymph nodes in pigs). Berl. Münch. tierärztl. Wschr. 1964, 77, 167-169 and $173-176$.

Lautrup-Nielsen, J. C.: Tuberkulose hos svinet. Morfologi, patogenese og differentialdiagnose. (Tuberculosis in pigs. Morphology, pathogenesis and differential diagnosis). Thesis, Den kgl. Veterinær- og Landbohøjskole, Copenhagen 1975.

Ray, J. A.: Diseases in swine resulting from experimental administration of Mycobacterium bovis, Mycobacterium avium, or Group III Mycobacteria. Thesis, Mich. State Univ., East Lansing 1966.

Thoen, C. O., D. W. Johnson, E. M. Himes, S. B. Menke \& C. C. Muscoplat: Experimentally induced Mycobacterium avium, Serotype 8 infection in swine. Amer. J. vet. Res. 1976, 37, 177-181.

Tuffley, R. E., J. H. Leggo, G. C. Simmons \& L. Tammemagi: Studies on the virulence of Mycobacterium intracellulare serotype VI for pigs. J. comp. Path. 1973, 83, 467-471.

Wayne, L. G.: Differentiation of mycobacteria by their effect on Tween $\circledast 80$. Amer. Rev. resp. Dis. 1962 a, 86, 579-581.

Wayne, $L$. G.: Two varieties of Mycobacterium kansasii with different clinical significance. Amer. Rev. resp. Dis. 1962 b, 86, 651-656. 


\section{SAMMENDRAG}

Infektionsfors $\phi g$ på svin med Mycobacterium avium, Serotype 2.

4. Kontaktsmitte fra svin podet per os.

I 3 eksperimenter blev ialt 13 grise podet peroralt med $0,5 \mathrm{mg}$ M. avium daglig i 5 dage $\left(1 \mathrm{mg}=32-68 \times 10^{6}\right.$ bakterier $)$.

Fem til 8 dage efter podningen blev 16 ikke-podede grise sat sammen med de podede.

Ved dyrkning fra gødningspr $\varnothing v e r$ kom vækst af M. avium fra alle de podede grise. Udskillelsesperioden lå mellem 16. og 65. dag efter podningen, og den maksimale udskillelse (62000 bakterier pr. $100 \mathrm{~g}$ gødning) fandtes ca. midt i perioden (Tabel 2). To af kontaktgrisene viste udskillelse af $M$. avium $i$ ringe antal, den ene gris 15. dag og den anden 37. og 44. dag efter kontaktsmittens begyndelse.

Post mortem unders $\varnothing$ gelser viste, at alle de inficerede grise havde tuberkul $\varnothing$ se forandringer.

Femten af 16 kontaktgrise viste tegn på smitteoverførsel enten ved tilstedeværelse af makroskopiske processer ( 5 grise) eller mikroskopiske processer (10 grise). Ni kontaktgrise var positive ved dyrkning.

(Received August 8, 1977).

Reprints may be requested from: J. Berg J $\emptyset$ rgensen, The State Veterinary Serum Laboratory, Bülowsvej 27, DK-1870 Copenhagen V, Denmark. 